\title{
AKUSTIIKAN TUTKIMUS ETNOMUSIKOLOGIASSA
}

Etnomusikologian keskeisenä ajatuksena on tutkia musiikkia osana kulttuuria. Etnomusikologisesti painottuneessa soitintutkimuksessa ei näin ollen olla kiinnostuneita vain soitinten ulkoisista tai akustisista ominaisuuksista, vaan halutaan esimerkiksi selvittää soittimiin liittyvät uskomukset. Akustiikan tutkimus luetaan luonnontieteelliseksi tutkimukseksi ja se on lähellä positivistista tutkimustraditiota, jolle on tyypillistä mm. mitattavuuden korostaminen. Tutkimuksen ulkopuolelle jätetään sellaiset tutkimuskohteet, jotka eivät ole tarkkojen - usein laboratorio-olosuhteissa tapahtuvien mittausten saavutettavissa. Näyttäisi siis siltä, että akustiikan tutkimus on kaukana etnomusikologien tutkimusihanteista. Sangen vähän onkin olemassa tutkimuksia, joissa akustiikkaan liittyviä kysymyksiä tarkasteltaisiin osana laajempaa kulttuurista kontekstia. Onko akustiikan tutkimuksella ylipäätään sijaa etnomusikologiassa?

Myös etnomusikologit ovat osoittaneet kiinnostusta vieraitten kulttuurien käyttämien soitinten ja ihmisäänen akustisille mittauksille. ${ }^{1}$ Etnomusikologisesti suuntautuneessa akustiikan tutkimuksessa pitäisi ottaa huomioon yhteisön jäsenten käsitykset akustisilta ominaisuuksiltaan erilaisten

1 Ks. esim. Hood 1971. 
soittimien asemasta, soittimiin liittyvistä uskomuksista eikä rajoittua vain tutkimaan eri soittimille tyypillisiä asteikkoja tai viritysjärjestelmiä. Yhdistämällä "kovilla" menetelmillä saatuja tietoja "pehmeämmillä" menetelmillä saatuihin tietoihin voidaan tutkimuskohteesta saada aikaisempaa syvällisempi ja monipuolisempi kuva.

Tässä artikkelissa pohdin akustisten mittausten merkitystä etnomusikologiassa ja annan esimerkkejä akustisista mittauksista ja niissä käytettävistä metodeista. Näen akustiikkaan kohdistuvan tutkimuksen etnomusikologista tutkimusta harjoittavan tutkijan yhtenä hyödyllisenä apuvälineenä. Akustiset mittaukset eivät saa olla itsetarkoitus, vaan niiden pitäisi antaa tutkijalle tietoa, jota voi käyttää etnomusikologisesti kiinnostavien tutkimusongelmien selvittämisessä.

Eri lähtökohdista akustiikkaa lähestyvien tutkijoiden lähestymistavoista otan esimerkiksi keskustelun, jonka kävin muutama vuosi sitten Irakissa sudanilaisen musiikintutkijan kanssa kanunissa käytettävästä viritysjärjestelmästä2 ${ }^{2}$ Keskustelun innoittajana oli se, että arabialaisessa musiikissa käytetään edelleen pythagoralaista viritysjärjestelmää. Sudanilaisen musiikintutkijan näkemys viritysjärjestelmistä poikkesi ratkaisevasti omastani. Etsin tiettyjen viritysjärjestelmien käytön syitä akustiikasta - lähinnä yläsäveljärjestelmästä -, hänen mukaansa viritysjärjestelmät sen sijaan heijastavat ihmisen ja jumalan välistä suhdetta ja ovat seurausta tästä suhteesta. Molempia tutkijoita kiinnosti akustiikkaan liittyvät ongelmat, mutta tapa jolla ongelmaa lähestyttiin oli tyystin erilainen: toinen tutkijoista korosti äänen fysikaalisia ominaisuuksia kun taas toinen korosti äänen yhteyttä uskontoon. Keskustelu herätti useita kysymyksiä: Kumpi lähestymistapa antaa relevantimpaa tietoa viritysjärjestelmistä? Kuinka etnomusikologin tulisi käyttää akustiikan tutkimuksen avulla saamiaan tietoja? Mihin seikkoihin etnomusikologin tulisi kiinnittää huomio akustisissa tutkimuksissa? Eroaako tai pitäisikö etnomusikologisen akustiikan tutkimuksen erota muusta akustiikan tutkimuksesta? Jos ne eroavat niin missä suhteessa? Kenties etnomusikologinen akustiikan tutkimus käyttää perinteisen akustiikan tutkimuksen metodeja, mutta tutkimusaiheen valinta ja tapa, jolla tuloksia käytetään, eroaa perinteisestä akustiikan tutkimuksesta?

Akustiikan tutkimus kohdistuu äänen fysikaalisiin ominaisuuksiin ja äänen liikkeisiin tilassa (huoneakustiikka) tai akustisten ilmöiden tulkintaan aivoissa (psykoakustiikka). Soitinakustiikassa tutkitaan mm. soitinten (ihmisäänen) osaäänesrakennetta, osaäänesten syttymisjärjestystä alukkeissa, osaäänesten keskinäisiä suhteita, rakennusmateriaalien vaikutusta osa-

2 Irak, Bagdad 1988. 
äänesrakenteeseen, eri putkityyppien ja äänenmuodostustapojen vaikutusta sointiväriin ja viritysjärjestelmiä. Akustiikassa ei ole sen sijaan sanottavasti tutkittu sellaisia kysymyksiä kuin miksi tietyt kulttuurit suosivat tiettyjä sointivärejä, mitä uskomuksia liittyy soitinten rakennusmateriaaleihin tai viritysjärjestelmiin tai kuinka soittimen akustiset ominaisuudet vaikuttavat musiikkiin.

Akustiikkaan liittyvillä ilmiöillä on todennäköisesti yhteys kulttuurissa vallitseviin musiikkiin liittyviin arvoihin ja uskomuksiin. Miksi arabialaisessa luutussa suositaan lyhyttä sointia tai joissain kulttuureissa nasaalia laulaääntä? Miksi laulajat käyttävät puhuessaaan eri äänenväriä kuin laulaessaan? Näihin kysymyksiin akustiikan tutkimus ei anna suoraa vastausta. Akustisilla mittauksilla voidaan sen sijaan selvittää, mitkä ovat tietyissä kulttuureissa suosittujen soitinten ominaisuudet ja kuinka eri soittimet eroavat akustisilta ominaisuuksiltaan. Tällöin soittimet, joihin akustinen mittaus kohdistuu, on valittu "etnomusikologisin" perustein. Karkeita mittauksia voidaan tosin tehdä korvan avulla ilman teknisiä mittalaitteita vaikkapa arvioimalla onko lauluääni nasaali tai karhea ${ }^{3}$. Dynamiikassa havaittavat muutokset saattavat kertoa olennaisia asioita laulajan tai soittajan tavasta hahmottaa musiikkia. Viritysjärjestelmien tai sävelkorkeuksien tutkiminen voi paljastaa kulttuurien välillä vallinneita tai vallitsevia yhteyksiä.

Etnomusikologi voi hyödyntää akustiikan tutkimusmenetelmiä useilla tavoilla. Perinteisen soitintutkimuksen lisäksi esityskäytäntöä ja erilaisia tulkintatraditioita voidaan tutkia käyttäen apuna äänen kuvauksessa käytettyjä menetelmiä kuten oskillogrammia, sonogrammia ja frekvenssikuvaajaa. Näitä voidaan käyttää apuna myös perinteisen länsimaisen nuotinnuksen laadinnassa. Seuraavassa annan esimerkkejä kustakin osa-alueesta ${ }^{4}$.

\section{Lomax 1968.}

4 Akustiset mittaukset olen tehnyt Macintosh tietokoneella. Oskillogrammit, sonogrammit ja frekvenssianalyysit olen suorittanut Signalyze-ohjelmalla. Spektrogrammianalyysi on mahdollista tehdä Sound Designer -ohjelmalla, osaäänesanalyysiin ja äänisynteesiin on käytettävissä Alchemy. Kahta viimeksi mainittua ohjelmaa en tämän artikkelin yhteydessä ole käyttänyt. Signalyze on edullinen ja monipuolinen puheen tai musiikin tutkimiseen hyvin soveltuva ohjelma. Sen on kehittänyt kanadalainen tutkija Eric Keller (Rosemere, Quebec J7A 1A9, Canada; fax: (514) 430-8522; e-mail: 76357.1213@COMPUSERVE.COM). Sound Designer ja Alchemy ovat lähinnä studiokäyttöön tarkoitettuja ohjelmia, joita voi käyttää - joskin rajoitetusti - myös tutkimuksessa. Suomalainen Macintosh-tietokoneelle kehitetty akustiikan tutkimukseen tarkoitettu tietokoneohjelma on ISA. Ohjelman kalleus johtuu osittain siitä, että tietokoneen lisäksi on hankittava erillinen signaaliprosessori. Ohjelmien ja niihin tarvittavien oheislaitteiden hinnat liikkuvat 2000 mk (Signalyze) ja 60000 mk (ISA) välillä. Signalyze tarvitsee äänen sisäänsyöttöä varten erillisen laitteen, jona voi käyttää mm. MacRecorderia. 


\section{Soitintutkimus}

Kanteleen äänelle pidetään tyypillisenä huojuntaa, joka johtuu kielen kiinnitystavasta nauloihin tai vartaaseen. Onko huojunta tyypillistä kaikille kanteleille ja mikä vaikutus esimerkiksi näppäilyn kohdalla on huojuntaan? Kanteleessa käytetään toisinaan metallikielten sijasta jouhikieliä. Mikä vaikutus kielimateriaalilla on kanteleen äänen ominaisuuksiin? Itäkarjalaisessa kanteleessa käytetään perinteisen varras- tai naulakiinnityksen lisäksi toisinaan tallaa. Mikä merkitys tallan käytöllä on kanteleen äänen kannalta? Edellä mainittuja seikkoja olen tutkinut oskillogrammin avulla. Metallikielisen ja jouhikielisen kanteleen esimerkeissä on 5-kielisenä kanteleena käytetty nk. Pokela-mallia. Tallalla varustetun kanteleen äänet on saatu itäkarjalaisesta kanteleesta ${ }^{5}$. Metallikielisen ja jouhikielisen kanteleen alukkeita olen tutkinut sonogrammin avulla ${ }^{6}$.

Kuvassa 1 on allekkain teräskielisen, jouhikielisen ja tallalla varustetun kanteleen oskillogrammi.

Kuva 1. Teräskielisen, jouhikielisen ja tallalla varustetun itäkarjalaisen kanteleen oskillogrammi (y-akseli kuvaa amplitudia, x-akseli kuvaa aikaa).

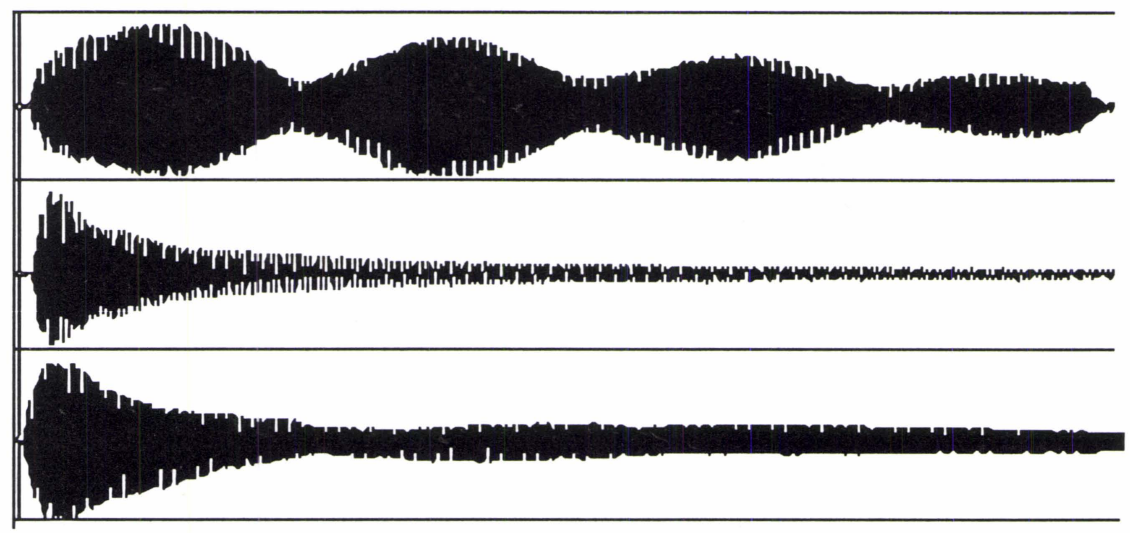

Jouhikielisen ja tallalla varustetun itäkarjalaisen kanteleen äänestä puuttuu

5 Kanteleena on ollut Kari Dahlblomin omistama kromaattinen kantele, jonka on valmistanut Ilmar Kukk Virossa 1970-luvun alkupuolella. Kyseisessä kanteleessa on kolmen oktaavin ääniala.

6 Sonogrammista tai spektrogrammista (molempia nimityksiä käytetään) nähdään äänen osaäänesrakenne ja osaäänesten voimakkuudet. Oskillogrammista nähdään mm. äänen amplitudi ajan funktiona. Signalyze-ohjelman frekvenssikuvaaja näyttää käyränä ensimmäisen osaääneksen taajuuden. Ohjelma voi seurata myös muiden osaäänesten taajuutta. 
huojunta lähes kokonaan ja ääni vaimenee selvästi nopeammin kuin metallikielisessä kanteleessa. Jouhikielisessä kanteleessa ääni vaimenee nopeiten. Mielenkiintoista olisi myös selvittää, mikä vaikutus kielimateriaalilla on musiikin tyyliin. Lyhytsointinen soitin sopii ilmeisesti huonommin tunnelmoivaan soittoon kuin virtuoosisoittoon. Pitkäsointisessa soittimessa nopeat soittokuviot puuroutuvat. Kuvassa 5 on sonogrammi, jossa on näkyvissä sekä metallikielisellä että jouhikielisellä kanteleella soitettua musiikkia. Kuvasta näkyy selvästi kielimateriaalin vaikutus sointiin. Soinnillisten erojen vuoksi jouhikanteleen ääni ei sulaudu metallikielisen kanteleen ääneen.

Kielen näppäilykohta on yhteydessä siihen, mistä huojunnan vaiheesta ääni alkaa. Soiton kannalta tällä ei todennäköisesti ole huomattavaa merkitystä muulloin kuin vahvistettaessa tai muokattaessa kanteleen ääntä elektronisesti. Alla olevassa kuvassa nähdään kaksi oskillogrammia. Ensimmäisessä oskillogrammissa ääni syttyy huojunnan alusta ja toisessa huojunnan loppupuolelta.

Kuva 2. Huojunnan eri vaiheet alukkeessa.

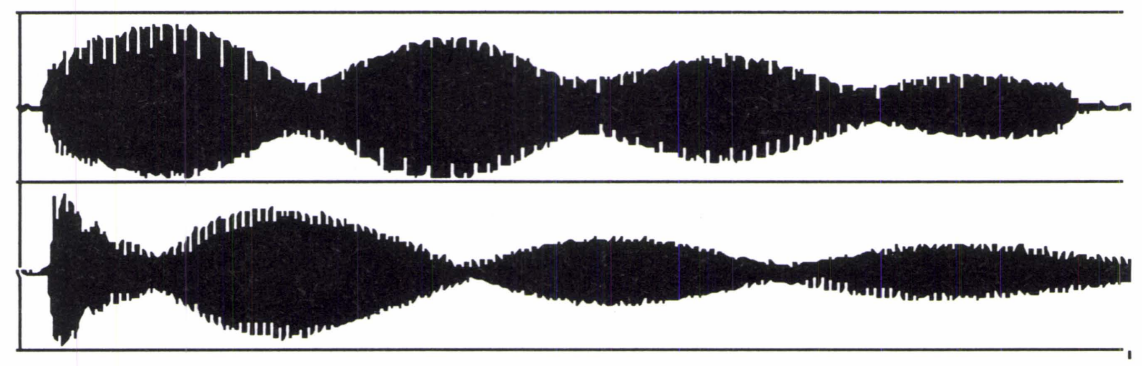

Kuvassa 3 on allekkain neljä oskillogrammia. Ne kuvaavat näppäilykohdan vaikutusta huojuntaan. Kokeessa käytin metallikieliä ja näppäilykohdan etäisyydeksi valitsin kanteleen toiseksi matalimman kielen viritystapin puoleisesta päästä lukien $4 \mathrm{~cm}, 16 \mathrm{~cm}, 24 \mathrm{~cm}$ ja $35 \mathrm{~cm}$. Kielen kokonaispituus on $38,5 \mathrm{~cm}$. 
Kuva 3. Näppäilykohdan vaikutus äänen huojuntaan.

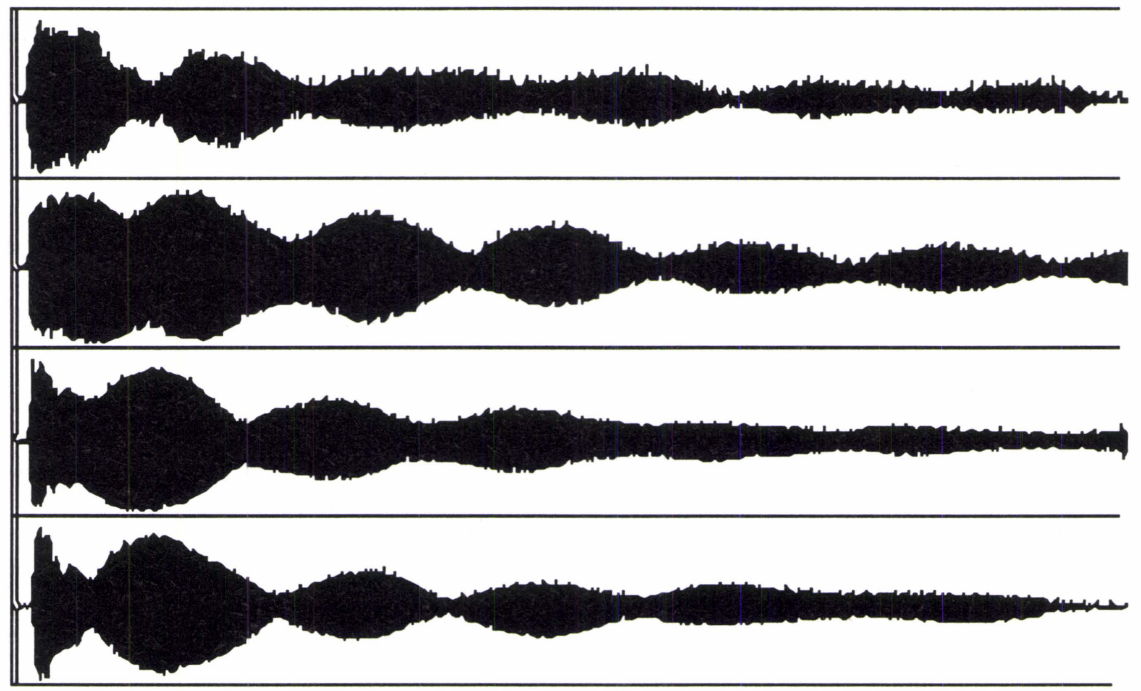

Metallikielistä ja jouhikielistä kanteletta kuunnellessa kiinnittyy huomio alukkeiden erilaisuuteen. Metallikielisessä tuntuu olevan kirkkaampi ja selkeämpi aluke kuin jouhikielisessä. Kuvassa 4 on metallikielisen ja jouhikielisen kanteleen aluke. Sävelet on soitettu toiseksi alimmalta kieleltä $(375 \mathrm{~Hz}$ ). Sonogrammi on otettu $0-5564 \mathrm{~Hz}$ taajuuskaistalta. Näyteen pituus on $100 \mathrm{~ms} \pm 1 \mathrm{~ms}$. 
Kuva 4. Metallikielisen ja jouhikielisen kanteleen sävelen aluke7

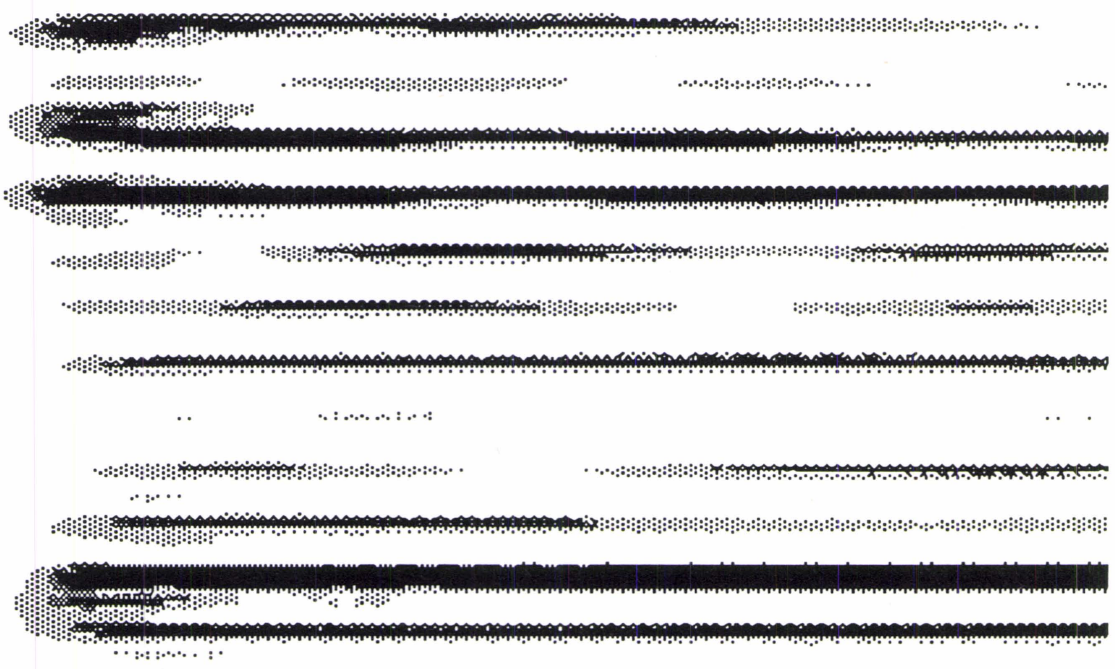

\section{Metallikielinen kantele}

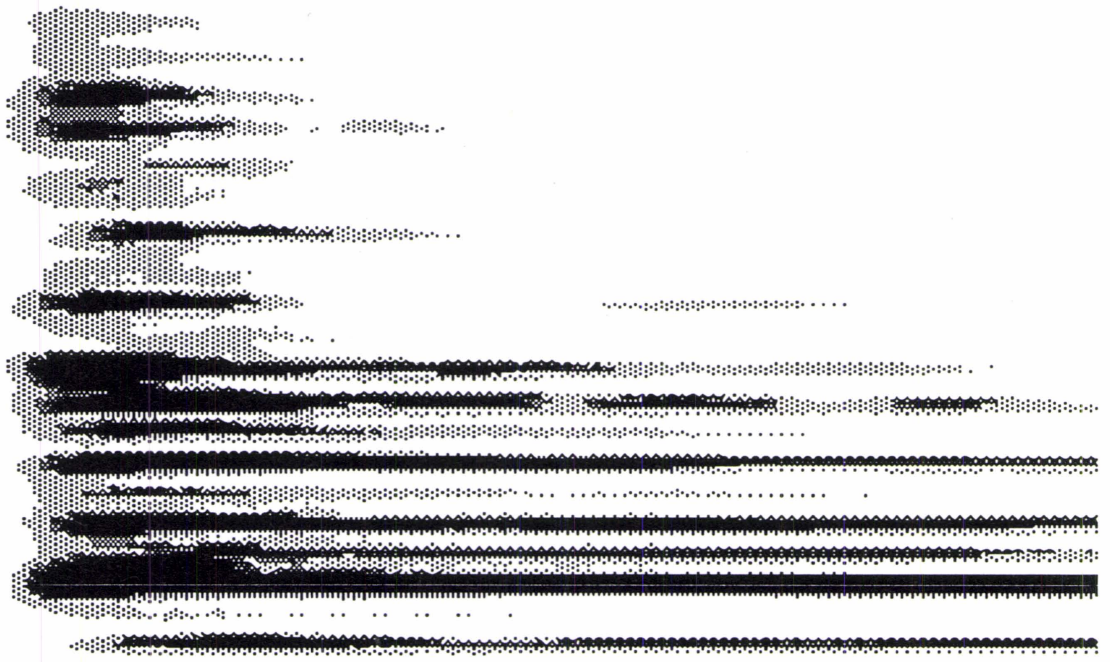

\section{Jouhikielinen kantele}

Molemmissa kanteleissa toinen osaäänes syttyy ennen ensimmäistä. Metal-

7 Y-akseli kuvaa frekvenssiä (osaäänesten taajuutta) ja x-akseli aikaa. Tummuus kuvaa osaäänesten amplitudia (äänienergian määrää). 
likielisessä kanteleessa korkeat osaäänekset ovat vahvemmin edustettuina kuin jouhikielisessä kanteleessa. Jouhikielisessä kanteleessa alukkeessa mukana olevat korkeat osaäänekset sammuvat nopeasti ja matalat osaäänekset jäävät soimaan. Tämä antaa jouhikieliselle kanteleelle tyypillisen tumman sävyn.

Edellä mainitut metalli- ja jouhikielisen kanteleen sointiin liittyvät seikat näkyvät havainnollisesti sonogrammista, joka on tehty Martti Pokelan sovittamasta itä-suomalaisesta tanssisävelmästä Ripatska ${ }^{8}$.

Kuva 5. Itä-suomalaisen tanssisävelmän sonogrammi. Sovituksessa on käytetty sekä jouhi- että metallikielistä kanteletta.

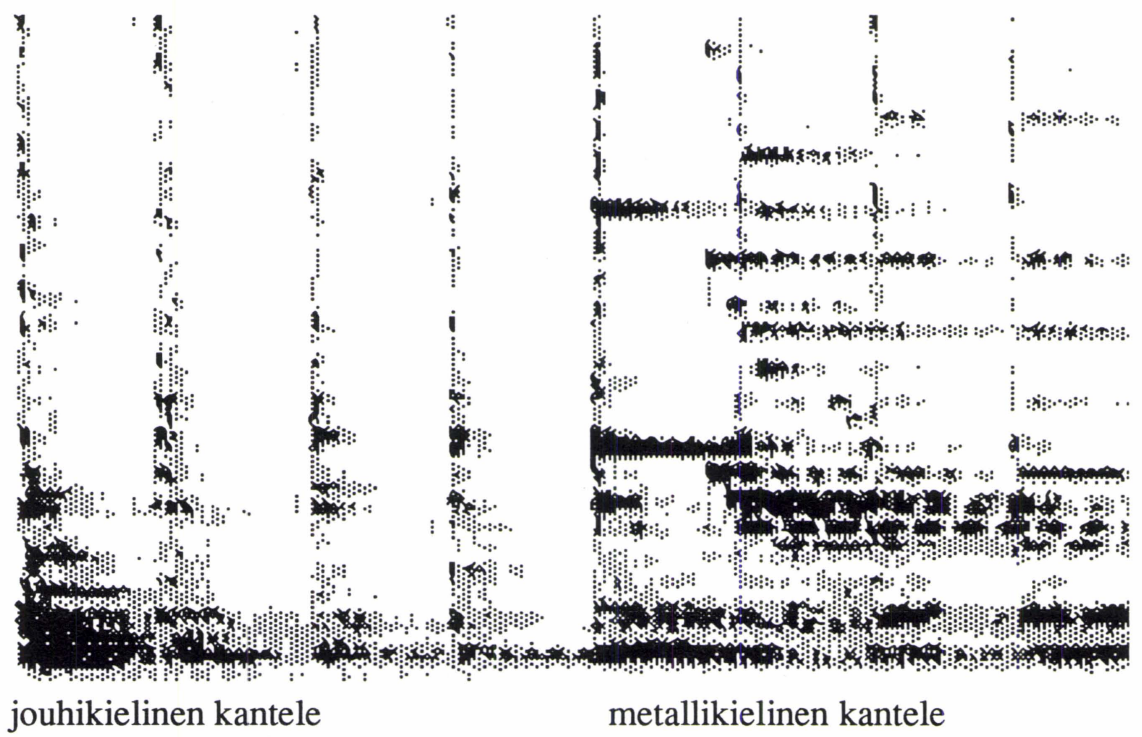

Sonogrammin avulla saa yleiskuvan myös sävelmän metrisestä rakenteesta. Erityisen hyvin metrinen rakenne näkyy jouhikielisen kanteleen osuudessa. Metallikielisen kanteleen osuudessa näkyy sävelten hitaampi vaimeneminen ja metallikielisen kanteleen rikkaampi yläsävelrakenne. Sovituksessa jouhikielisen kanteleen äänen akustisia ominaisuuksia on käytetty taitavasti hyväksi. Lyhyen sointinsa ansiosta jouhikielinen kantele sopii metallikielistä paremmin rytmikkäisiin jaksoihin.

8 Vanha ja uusi kantele. 1978. Finnlevy SFLP 8578. 


\section{Nuotinnus}

Kansanmusiikin tutkimuksessa on ollut vuosikymmeniä ongelmana nuotinnus. Ongelma koskee toisaalta arkistoissa olevien tallenteiden nuotintamisen nopeutta ja toisaalta nuotinnusten tarkkuutta ja käytettyä nuotinnustapaa. Musiikkia voi tutkia mielekkäästi ilman nuotintamistakin, mutta tästä huolimatta nuotintamisella on edelleen tärkeä asema etnomusikologisessa tutkimuksessa. On kuitenkin syytä pohtia sitä, onko yksinomaan perinteisen länsimaisen notaation käyttö mielekästä etnomusikologisessa tutkimuksessa? Musiikin yksinkertaistettu kuvaus on tarpeen esimerkiksi sävelmäluetteloissa ja länsimaiseen nuottikirjoitukseen tottuneelle nuottien käyttö on luonnollinen ratkaisu. Paljon käytetty vaihtoehto on myös nuotteihin pohjautuvien aakkosellisten rekisterien käyttö ${ }^{9}$. Länsimainen nuottikirjoitus on kehitetty tai kehittynyt palvelemaan muusikoiden, ei tutkijoiden tarpeita. Koska länsimainen notaatio on kehitetty ennen kaikkea länsimaisen taidemusiikin muistiin merkitsemiseen, se ei välttämättä palvele yhtä hyvin muiden kulttuurien musiikkien muistiin merkitsemistä. Esimerkiksi monimutkaisia ornamentteja sisältävien sävelkulkujen vangitseminen länsimaisella notaatiolla on ongelmallista. Lisäksi länsimainen nuottikirjoitus jättää monia tärkeitä musiikin parametreja huomioimatta, kuten sointivärin. Eikö olisi syytä miettiä vaihtoehtoja?

Länsimaisen notaation sijasta tai lisäksi musiikin kuvaamiseen on käytetty ainakin kolmea eri tapaa: oskillogrammia, sonogrammia ja frekvenssikuvaajaa $^{10}$. Näiden kuvaustapojen avulla saadaan havainnollisen yleiskuvan lisäksi tarkkaa tietoa voimakkuusvaihteluista, sointiväristä, sävelkorkeuksista ja sävelten kestosta. Myös musiikin metrinen rakenne on nähtävissä, joskaan ei niin helposti kuin perinteisestä nuottikirjoituksesta. Oskillogrammin avulla nähdään dynaamiset vaihtelut, sonogrammi näyttää sointivärissä ja frekvenssikuvaaja sävelkorkeudessa tapahtuvat muutokset. Frekvenssikuvaajaa voi käyttää joko sävelkorkeuksien yksityiskohtaiseen analyysiin, melodisen kaarroksen tarkasteluun tai nuotinnuksen apuna. Soittotapaan liittyviä seikkoja edellä mainitut kuvaustavat eivät ainakaan suoraan paljasta. Sonogrammien käytön yhtenä ongelmana on se, että ne sisältävät enemmän informaatiota kuin mitä ihminen ilmeisesti käyttää musiikkia hahmottaessaan ${ }^{11}$.

9 Aihetta olen käsitellyt tarkemmin toisissa yhteyksissä. Ks. Louhivuori 1988 a, 1-22; 1988 b, 95-115.

10 Uppsalan yliopiston musiikkitieteen laitoksella äänen akustiikkaan ja automaattiseen nuotinnukseen liittyviä tutkimuksia on tehty jo 1960-luvulta alkaen. Ks. Thorsén 1972.

11 On syytä korostaa myös sitä seikkaa, että kuulijan hahmottama sävelkorkeus ja sävelen fysikaalisesti mitattava taajuus on kaksi eri asiaa. Ihminen ei tulkitse taajuuksia 
Tarkastelen seuraavassa nuotinnukseen liittyviä seikkoja beduiinilaulun ja moldavialaisen kansanlaulun avulla.

Runsaasti ja monimutkaisesti ornamentoitua laulua on vaikea nuotintaa varsinkin silloin, jos laulusta puuttuu selvä metrinen rakenne. Kuvassa 6 on Irakista äänittämääni beduiinilaulua ${ }^{12}$. Näytteessä on tuntemattomalta laulajalta kaksi saman säkeen toisintoa. Säkeen $b$ ambitus on noin tritonus (h - f1). Kuvassa on sekä frekvenssikuvaaja että oskillogrammi.

Kuva 6. Kaksi irakilaisen beduiinin esittämää säkeen toisintoa.

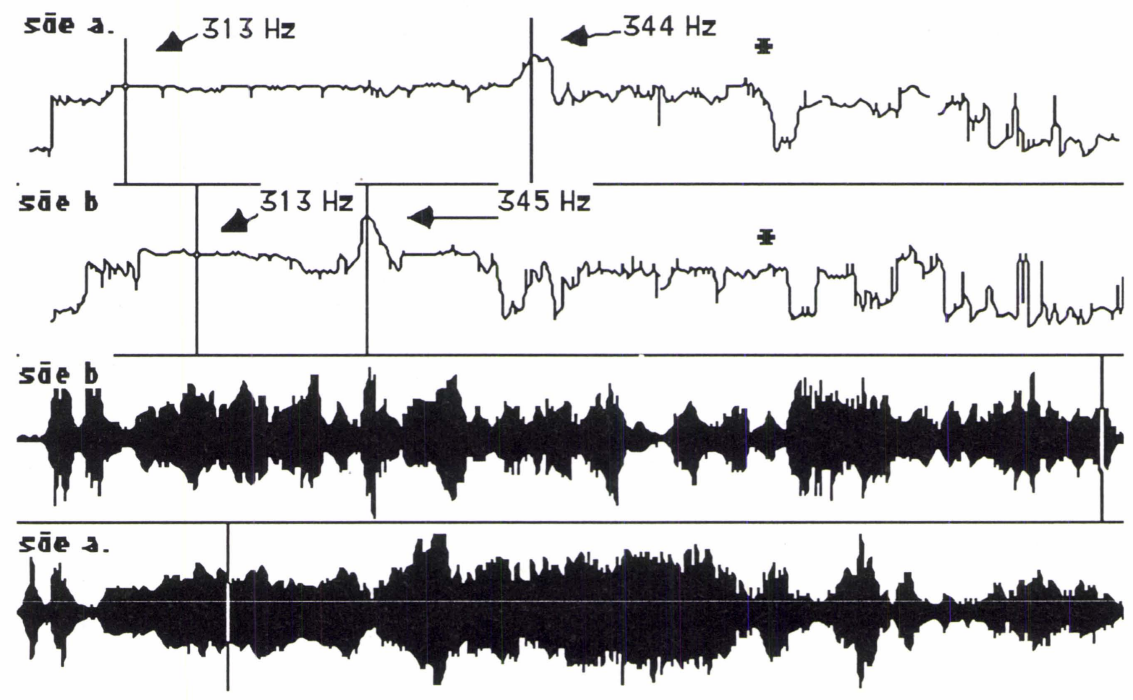

Kuvasta näkyy beduiinilaululle tyypillinen melodiakaarros: Nousevan kahden sävelen mittaisen alun jälkeen seuraa pitkä sävel $(313 \mathrm{~Hz})$. Sitä seuraavan lakisävelen $(344 / 345 \mathrm{~Hz})$ jälkeen melodia laskeutuu asteittain alaspäin säkeen päätössäveleeseen $(250 \mathrm{~Hz})$. Säkeen jälkipuolelle on ominaista voimakas vibrato, joka näkyy selvemmin kuvassa 7. Siinä kuva 6 on suurennettu tähdellä merkitystä kohdasta alkaen.

suoraviivaisesti, vaan sävelkorkeuteen vaikuttavat monet psykoakustiset ja psykologiset seikat. Esimerkiksi äänen voimakkuus ja osaäänesrakenne on yhteydessä sävelkorkeuden hahmottamiseen. Taajuuden ja säveltason välistä suhdetta kuvataan mel-käyrällä (Handel 1989, 69).

12 Äänityksen olen tehnyt Irakissa (Bagdad) elokuussa 1988. 
Kuva 7. Kuva 6 suurennettuna.

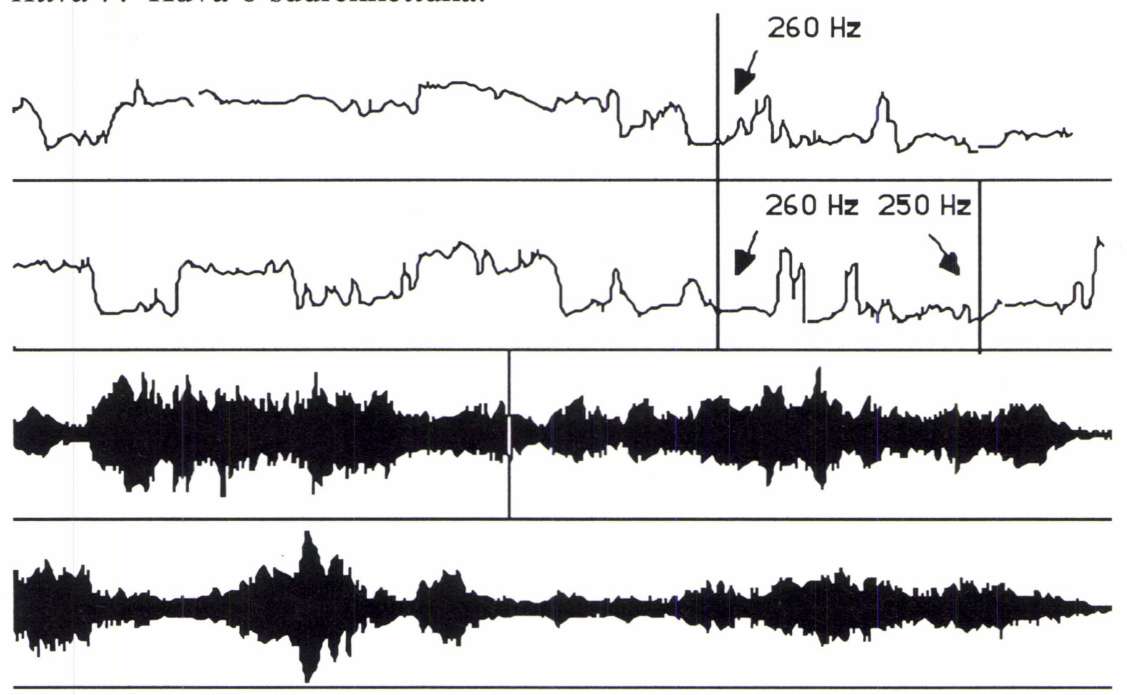

Béla Bartókin moldavialaisen kansanmusiikin nuotinnuksissa kiinnittyy huomio lukuisten ornamenttien lisäksi lisämerkkeihin, joilla Bartók on merkinnyt diatonisen asteikon kannalta liian korkeat sävelet. Kuvassa 8 olen vertaillut Bartókin tekemää kansanlaulun nuotinnusta frekvenssikuvaajaan $^{13}$. Laulu on tallennettu Sekin kylästä kotoisin olevalta naiselta, mutta äänitys on tehty studiossa. Kuvasta huomataan, että nuotinnus noudattaa sangen tarkasti frekvenssikuvaajaa ${ }^{14}$.

13 Laulaja on 45 vuoden ikäinen Ferenc Szabó Trunkin kylästä (Moldavia, Romania). Äänitys on tehty 28. toukokuuta 1938 Budapestissa. Äänite on levyltä Ethnic Folkways Library P 1000, Hungarina Folk Songs (toim. Péter Bártok).

14 Liitteessä 1 nuotinnus on kokonaisuudessaan. 
Kuva 8. Kaksi säettä Bartókin nuotintamasta moldavialaisesta laulusta ja säkeiden frekvenssikuvaajat. Nuolella merkityt sävelet ovat n. $320 \mathrm{~Hz}$ (318-321 Hz).

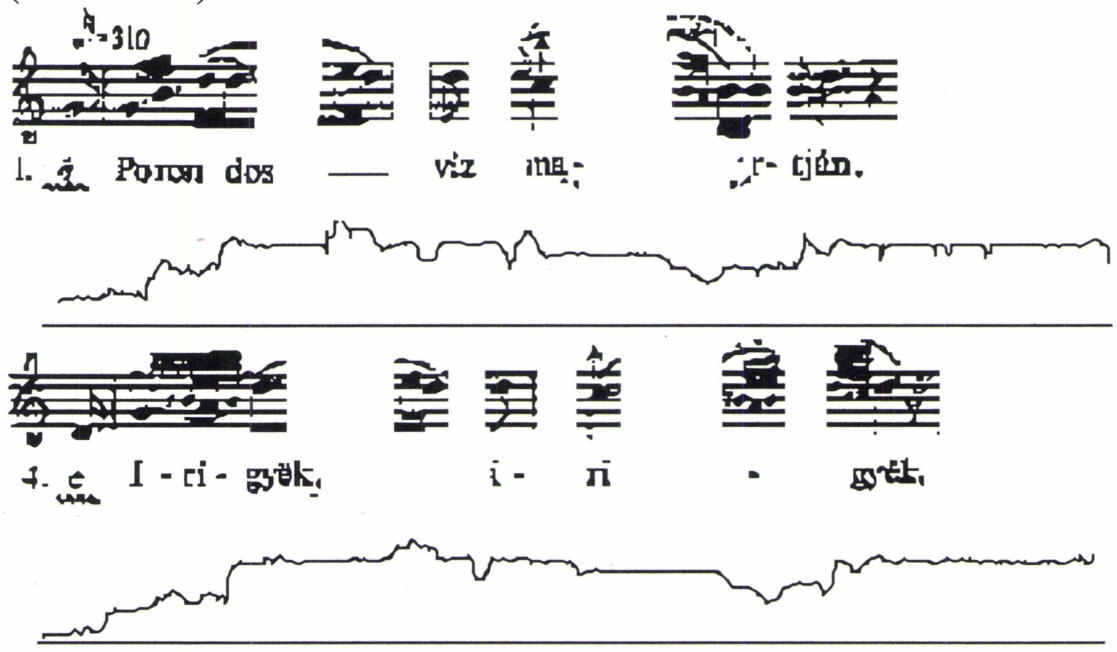

\section{Esityskäytäntö ja tulkintatraditiot}

Akustisia mittauksia voidaan käyttää apuna esityskäytännön tutkimuksessa. Tätä sovellusaluetta pidän etnomusikologian kannalta erityisen kiinnostavana ${ }^{15}$. Seuraavassa tarkastelen edellä käyttäämääni Bartókin tallentamaa moldavialaista kansanlaulua. Laulussa kiinnittyy huomion diatoniseen asteikkoon kuulumattomaan säveleen, korkeaan kvarttiin, joka on matalampi kuin ylennetty kvartti, mutta korkeampi kuin puhdas kvartti. Bartók on merkinnyt nuotinnuksiin kyseisiin kohtiin ylöspäin osoittavan nuolen ${ }^{16}$. Arpád Joob on löytänyt moldavialaisista kansanlauluista kolme erilaista kvarttia. Perussävelen ollessa $223 \mathrm{~Hz}$ pitäisi puhtaan kvartin olla $297 \mathrm{~Hz}$, mutta laulaja käytti $314 \mathrm{~Hz}$ taajuista kvarttia. Toisessa tapauksessa perussävel oli $163 \mathrm{~Hz}$, laulajan käyttämä "puhdas kvartti" oli $217 \mathrm{~Hz}$, ylinouseva kvartti $235 \mathrm{~Hz}$ ja korkea kvartti $222 \mathrm{~Hz}^{17}$. Kolmen erilaisen kvartin

15 Esityskäytäntöä ovat tutkineet akustisilla mittalaitteilla mm. Gabrielson (1988, 27-51) ja Rasch (1988,70-90).

16 Ks. kuva 8 ja liite 1.

17 Joob 1991. Akustisissa mittauksissa käytetään yleensä Hz-asteikon sijasta centtiasteikkoa, koska centtiasteikon antamia tuloksia on helpompi verrata toisiinsa kuin hertseinä ilmaistuja taajuuksia. Centtiasteikossa oktaavi on jaettu 1200 centtiin, jolloin puoliaskel on 100 centtiä. Hertsien käytössä mittayksikkönä on ongelmana se, että esim. puoliaskelten suuruus riippuu säveltasoista. Pienen oktaavin a- ja b-sävelen ero on $233.08 \mathrm{~Hz}-220$ $\mathrm{Hz}$ eli $13.08 \mathrm{~Hz}$, kun taas ensimmäisessä oktaavialassa a- ja b-sävelen ero on $466.16 \mathrm{~Hz}$ $440 \mathrm{~Hz}$ eli $26.16 \mathrm{~Hz}$. Centteinä mitattuna ero on molemmissa oktaavialoissa sama eli 100 
käyttö on johdonmukaista eikä kyseessä ole epätarkasta laulusta johtuva ylävireisyys. Tähän viittaa jo se, että laulaja on sävelkorkeuksissa erittäin tarkka: viiden säkeistön aikana melodian tukisävelet pysyvät täsmälleen samoina.

Kuvassa 9 olen verrannut kolmen säkeistön tulkintoja keskenään, kuudennesta säkeistöstä olen ottanut mukaan myös oskillogrammin. Vertailusta huomataan, että d-sävel on kaikissa säkeistöissä sama $(695 \mathrm{~Hz})$. Sävelten kestoissa on sen sijaan suurempia eroja.

Kuva 9. Moldavialaisen kansanlaulun kolmen säkeistön (3, 5 ja 6 säkeistö) ensimmäiset säkeet ja kuudennen säkeistön ensimmäisen säkeen oskillogrammi.

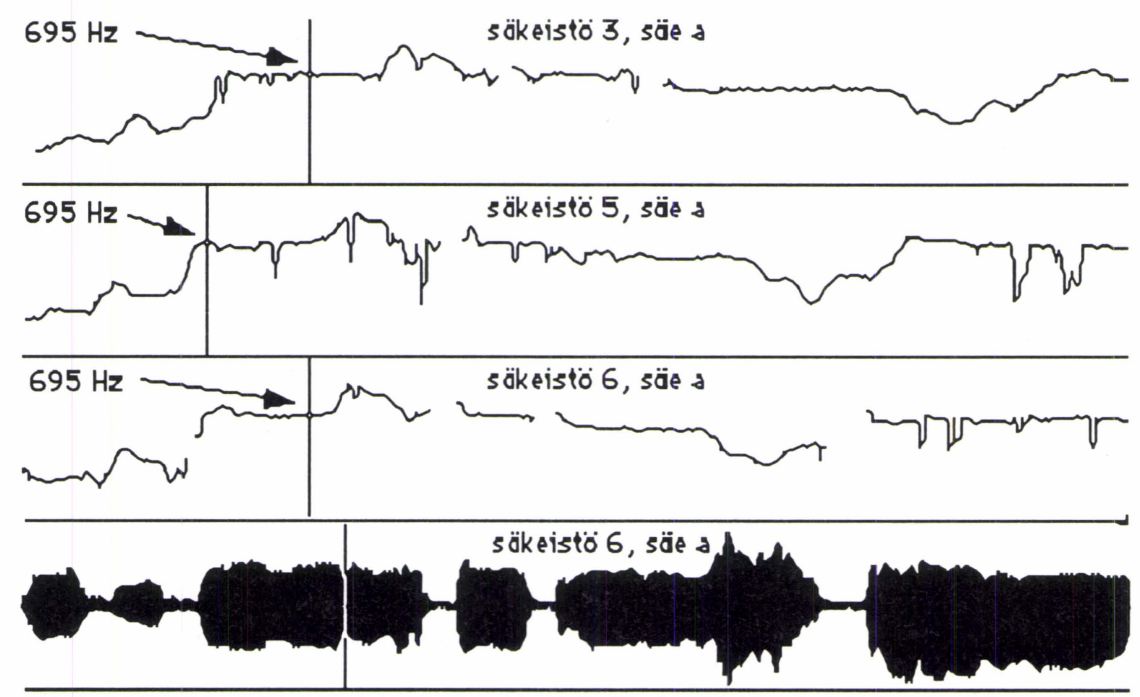

Etnomusikologia tutkii musiikkia osana kulttuuria, mutta harvemmin tutkimuksissa otetaan huomioon eläinten ja ihmisten välinen kommunikaatio. Karjankutsut ovat parhaimmillaan musiikillisesti rikkaita ja taidokkaita. Seuraavassa kuvassa on Taalainmaalta vuonna 1954 tallennettua karjankutsuntaa, jossa laulaja päättää säkeen täsmälleen samaan sävelkorkeuteen, jota lehmä käyttää vastatessaan emännän kutsuun ${ }^{18}$.

centtiä.

18 Laulaja: Karin Edvard Johansson (s. 1909 Högstrand, Trandstrand). Locklåtar och musik på horn och pipa. SRLP 5017. 
Kuva 10. Karjankutsujan ja lehmän välinen vuoropuhelu.

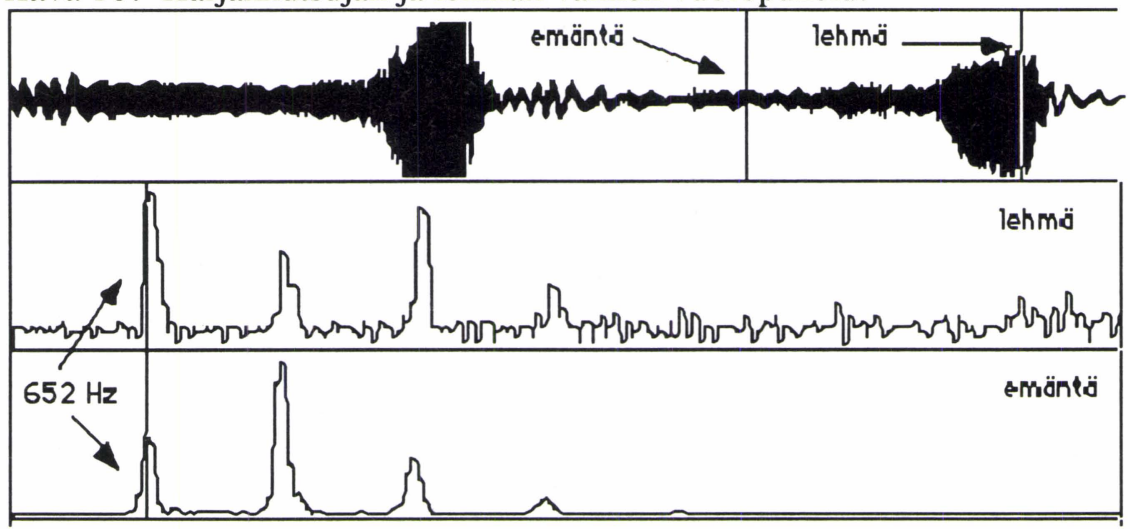

Kuvassa 10 oskillogrammin alapuolella on näyte emännän ja lehmän osaäänesrakenteesta oskillogrammissa nuolilla osoitetuista kohdista. Perustaajuus molemmissa kohdissa on $652 \mathrm{~Hz}$. Kuvassa 11 kiinnittyy huomio suoraan äänenkäyttöön ja äänen korkeuteen: laulaja ei käytä vibratoa juuri lainkaan ja korkein laulettu sävel on peräti $1391 \mathrm{~Hz}^{19}$.

Kuva 11. Karjankutsunnassa ei käytetä juuri lainkaan vibratoa. Ympyröity kohta on kuvassa $11 \mathrm{~b}$ suurennettuna.

a.
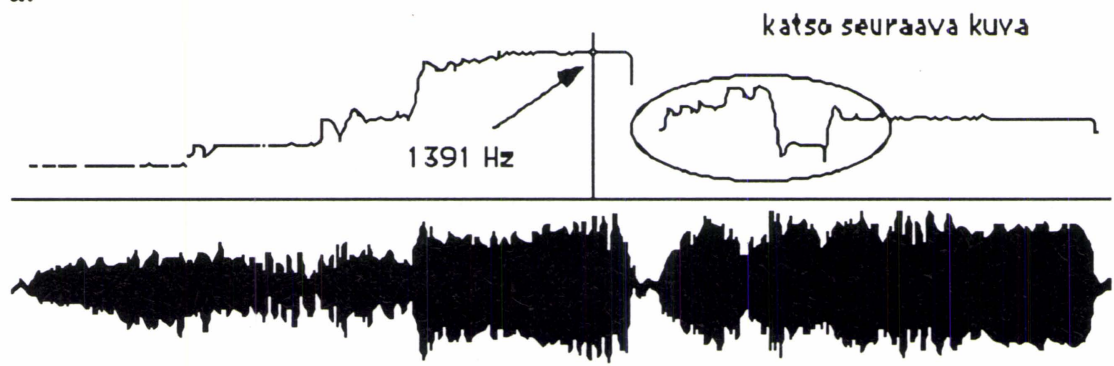

b.

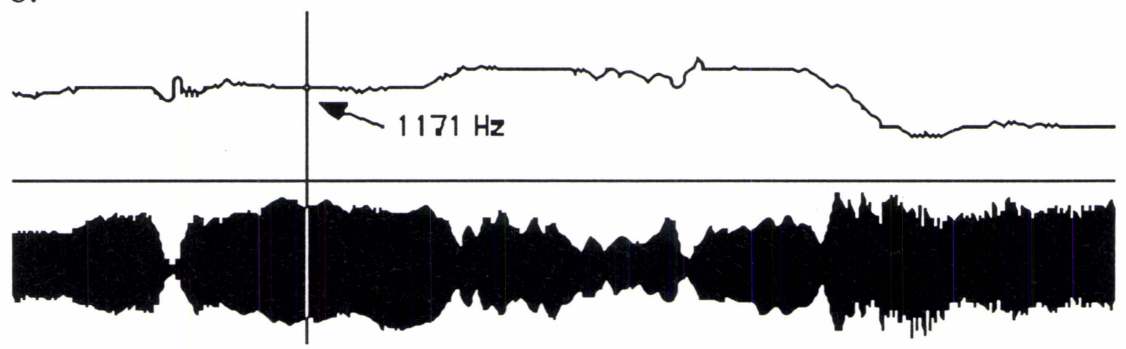

19 Vrt. Mozartin Taikahuilu-oopperan Yön kuningattaren aariaan, jossa korkein sävel (f3) on $1396.9 \mathrm{~Hz}$ (pienen oktaavin a:n ollessa $440 \mathrm{~Hz}$ ). 


\section{Päätteeksi}

Etnomusikologinen akustiikan tutkimus ei eroa muusta akustiikan tutkimuksesta menetelmiltään. Tutkimuskohteiden valintatapa ja tulosten tulkinta tai käyttö sen sijaan eroaa. Etnomusikologi ei tutki akustisia ilmiöitä niiden itsensä vuoksi, vaan selvittääkseen jonkin etnomusikologisesti kiinnostavan kysymyksen. Jos esimerkiksi itäkarjalainen kanteleensoittotyyli poikkeaa suomalaisesta kanteleensoitosta, voidaan eron syytä etsiä myös soittimen äänen akustisista ominaisuuksista. Tällöin tulee mieleen äänen alukkeen ominaisuudet ja sävelen vaimenemisessa havaitut erot. Lyhyemmän soinnin ansioista itäkarjalainen kantele sopii nopeaan ja virtuoosiseen soittoon, koska sävelet eivät sekoitu toisiinsa yhtä paljon kuin suomalaisessa kanteleessa. Sama koskee metallikielisen ja jouhikielisen kanteleen eroa (ks. kuva 5). Akustisia mittauksia voidaan käyttää myös eri tulkintatyylien analysoimisessa ja nuotinnuksen apuna. Etnomusikologi voi akustisten mittausten avulla syventää tietämystään kulttuurisesti kiinnostavista akustiikkaan liittyvistä ilmiöistä. Etnomusikologi pääsee akustisten mittausten ja graafisten kuvausten avulla tarkastelemaan tutkittavia ilmöitä aikaisempaa yksityiskohtaisemmin ja havainnollisemmin eikä kenties arvokasta informaatiota jää ottamatta huomioon tutkimusaineiston analyysissa ja tulosten tulkinnassa. Mittausten etuna on myös se, että niiden avulla voidaan vähentää subjektiivisesta kuulemisesta aiheutuvia ongelmia. Kokeneenkin tutkijan on vaikea välttää aikaisempien kokemustensa ja odotustensa vaikutusta siihen, kuinka hän tulkitsee kuulemansa.

\section{Lähteet}

Backus, J.

1977 The acoustical foundations of music. 2. painos. New York. Benade, A.H.

1976 Fundamentals of musical acoustics. London. Benade, A.H., Larson, C.O.

1985 "Requirements and techniques for measuring the musical spectrum of the clarinet." Journal of the Acoustical Society of America, 78 (5), 1475-1498.

Campbell, $\mathrm{M}$.

1987 The musician's guide to acoustics. London.

Castellano, M.A., Bharucha, J.J., Krumhansl, C.L.

1984 Tonal hierarchies in the music of North India. Journal of 
Experimental Psychology: General, 113 (3), 394-412.

Ericson, R.

1976 Sound structure in music. Berkeley.

Gabrielson, A.

1988 "Timing in music performance and its relations to music experience." Kirjassa Sloboda, J.A. (toim.), Generative Processes in Music. (s. 27-51). Oxford.

Green, D.M.

1976 An introduction to hearing. Hillsdale, N.J.

Gulick, W. L.

1989 Hearing: physiological acoustics, neural coding, and psychoacoustics. Oxford.

Hall, D.E.

1980 Musical acoustics: An introduction. Belmont, California. Handel,

1989 Listening. An Introduction to the Perception of Auditory Events. Cambridge, Massachusetts.

Hood, M.

1976 The Ethnomusicologist. New York.

Ihde, D.

1976 Listening and voice. A phenomenology of sound. Athens.

Kessler, E.J., Hanson, C., Shepard, R.N.

1984 "Tonal schemata in the perception of music in Bali and in the West." Music Perception, 2(2), 131-165.

Krumhansl, C. L.

1990 Cognitive foundations of musical pitch. New York. Lomax, A.

1968 Folk song style and culture. Washington.

Louhivuori, J.

1988 a) "Sävelmärekisterin laadinnan ongelmia." Musiikki 3-4, 122. Helsinki.

Louhivuori, J.

1988 b) Veisuun vaihtoehdot. Musiikillinen distribuutio ja kognitiiviset toiminnot. Acta Musicologica Fennica 16. Helsinki.

McIntyre, M.E., Schumacher, R.T., Woodhouse, J.

1978 "The acoustics of stringed musical instruments." Interdisciplinary Science Reviews, 3(2), 157-173. 
McIntyre, M.E., Schumacher, R.T., Woodhouse, J.

1983 "On the oscillations of musical instruments." Journal of the Acoustical Society of America, 74 (5), 1325-1345.

Pierce, J.R.

1983 The science of musical sound. New York.

Plomp, R.

1975 Aspects of tone sensation. London.

dePolli, G., Piccialli, A., Roads, C. (toim.)

1991 Representations of Musical Signals. Cambridge, Massachusetts.

Pressing, J.

1983 "Cognitive isomorphisms in pitch and rhythm in world musics: West Africa, the Balkans, Thailand, and Western tonality." Studies in Music, 17, 38-61.

Rasch, A.R.

1988 "Timing and synchronization in ensemble performance." Kirjassa Sloboda, J.A. (toim.), Generative Processes in Music. (s. 70-90). Oxford.

Risset, J.C., Wessel, D.L.

1982 "Exploration of timbre by analysis and synthesis." Kirjassa

D. Deutsch (toim.), The psychology of music (s. 26-58). New York.

Roederer, J.G.

1975 Introduction to the physics and psychophysics of music. New York.

Sloboda J. A. (toim.)

1988 Generative processes in music: the psychology of performance, improvisation, and composition. Oxford.

Sundberg, J.

1977 "The acoustics of singing voice." Scientific American, 236(3), 82-91.

Taylor, C.

1976 Sound of music. New York.

Thorsén, S-M.

1972 POLLY - en ljudanalysator för flerstämmig musik. Uppsala universitet.

Ward, W.D.

1954 "Subjective musical pitch." Journal of the Acoustical Society of America, 26(3), 369-380.

Yost, W.A., Nielsen, D.W. 
1985 Fundamentals of hearing. 2. painos. New York.

Painamattomat lähteet

Joob, A. (1991) Esitelmä Jyväskylän yliopiston musiikkitieteen laitoksella 5.4.1991.

Ä̈̈nitteet

Beduiinilaulua. Kasetti äänitetty Irakissa (Bagdad) 1988. Jukka Louhivuoren kasettikokoelma.

Hungarina Folk Songs (toim. Péter Bártok) Ethnic Folkways Library P 1000. Budapest.

Locklåtar och musik på horn och pipa. SRLP 5017.

Vanha ja uusi kantele (1978) Finnlevy. SFLP 8578. 


\section{LIITE 1}

$$
45 / a, b)
$$

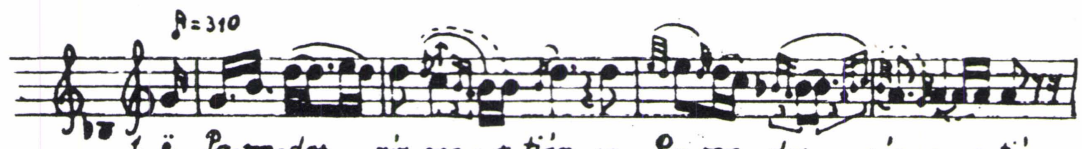

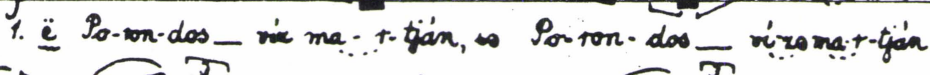

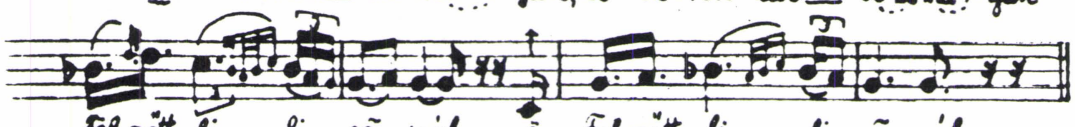

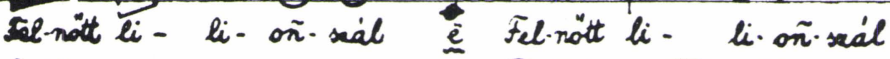

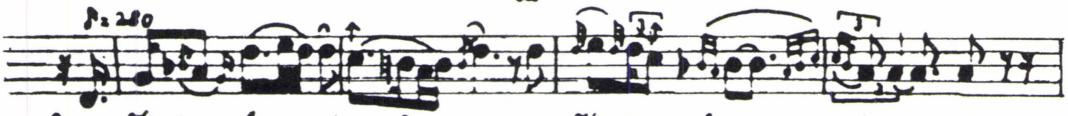

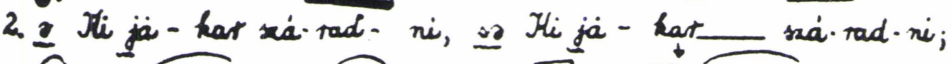

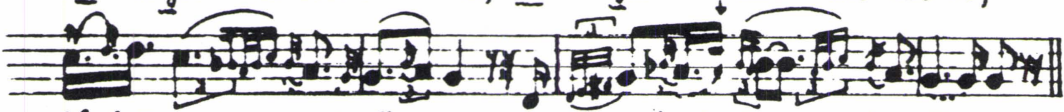

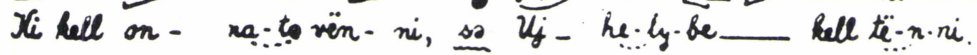

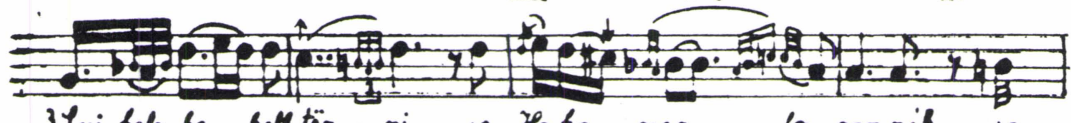

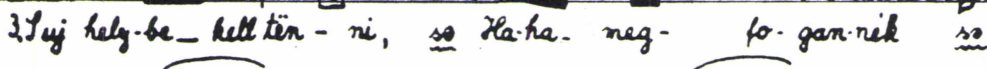

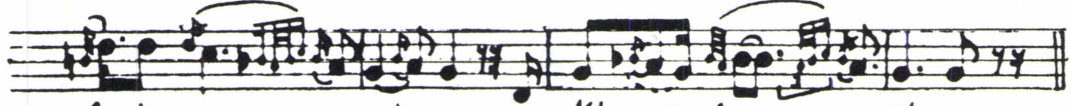
A in se. ren-cabare, is Marna.to busen. já-ta.

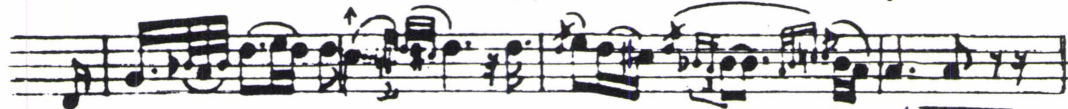

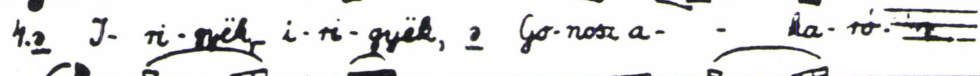

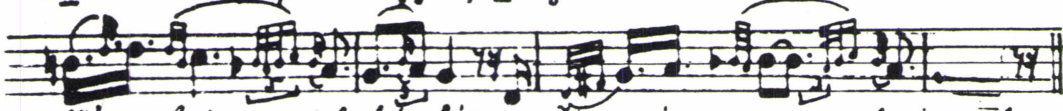
Nigem hat - tol be- hit : Sen - at - van fe-jen =l, 1. 5.7in át.va - k.jem - nek, hieginy i- - le-tim-nek?

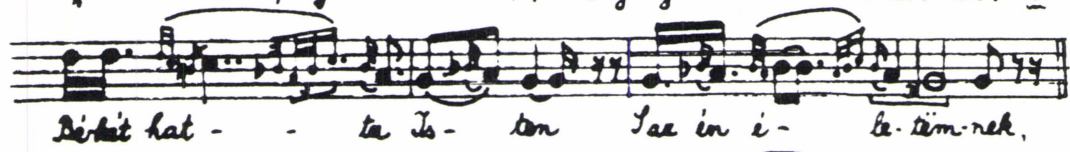

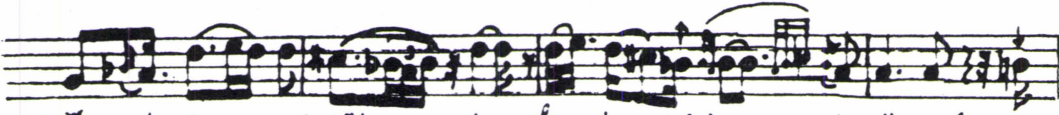

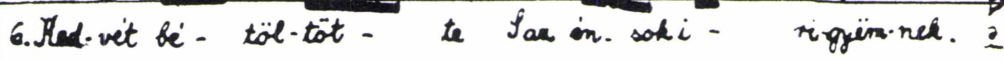

